\title{
Evaluating White Pine Blister Rust Resistance in Ribes after Artificial Inoculation
}

Paul J. Zambino

\begin{abstract}
AdDitional INDEX words. black currant, Cronarti um ribicola, urediniospore, teliospore, $\mathrm{R}$ ibesnigrum, $\mathrm{R}$ ibes rubrum.

Summary. Artificially inoculated single-leaf cuttings and small plants consistently differentiated european black currant ( $R$ i besni grum L.) cultivars susceptible to white pine blister rust (WPBR; C ronartium ribicola J.C. Fisch.) from immune cultivars carrying the $\mathrm{Cr}$ resistance gene. B lack currant cultivars Consort, C rusader, and Titania showed no signs of infection with any of 21 strains of WPBR, suggesting that strains able to overcome immunity conferred by the $\mathrm{Cr}$ resistance gene, if they exist, are uncommon in $\mathrm{N}$ orth America. $\mathrm{H}$ owever, in red currant ( $R$ ibesrubrum L.), two sources of material presumed to represent the immune cultivar Viking showed no resistance to infection. All rust strains infected and sporulated as if the cultivar were fully susceptible, casting doubt on the true identity of available sources of ' $V$ iking'.
\end{abstract}

W hite pine blister rust can cause multiple cycles of urediniospore production and infection on leaves of susceptible currants and gooseberries ( $R$ ibes L .) during the growing season, leading to premature leaf drop. U nder cool conditions, infected leaves also produce hairlike columns of teliospores. Basidiospores released from teliospores during cool, moist conditions infect needles of five-needle pines (Pinus L.). The cankers that subsequently form in branches and stems reduce the number of living branches in crowns and girdle trunks, causing widespread mortality. D evelopment and use of resistant currant cultivars in areas where commercial currant production occurs in close proximity to white pine forests provide a strategy for minimizing losses in both hosts. The present study describes artificial inoculation of young cuttings non destructively sampled from actively growing plants and inoculation of small plants grown from rooted cuttings as methods of rapidly identifying immune forms of resistance in currants.

\section{Materials and methods}

$\mathrm{R}$ ibes used in the study were immune european black currant cultivars Consort, C rusader, and Titania carrying the dominant $\mathrm{Cr}$ resistance gene from $\mathrm{R}$. ussuriense Jancz. (Brennan, 1996); susceptible black currant cultivars Boskoop Giant, Ben Alder, and Ben Lomand; two independent sources presumed to represent the immune red currant cultivar Viking (syn. 'Rød H ollandsk D ruerips') which carries an unnamed dominant resistance gene from R . petraeum Wulf. (H ahn, 1943); and susceptible red currant cultivar Red Lake.

U SD A Forest Service, Placerville N ursery, 2375 Fruitridge Road, C amino, CA 95709; research conducted at N orth Central Research Station, Forestry Sciences Laboratory, $5985 \mathrm{H}$ wy. K, Rhinelander, WI, 54501; e-mail pzambino@fs.fed.us.

The cost of publishing this paper was defrayed in part by the payment of page charges. U nder postal regulations, this paper therefore must be hereby marked advertisement solely to indicate this fact. 
Four types of plant materialswere inoculated: softwood cuttings with a single young but fully expanded, subterminal leaf; similar cuttings allowed to mature for 3 weeks after cutting; rooted plants grown from recent cuttings and having at least six leaves; and similar plants in which shoot growth had ceased and all leaves were fully hardened.

To provide uniformity among inoculations, aliquots of WPBR urediniospores had been viably stored in heat-sealed plastic envelopes at - 80 ${ }^{\circ} \mathrm{C}\left(-112^{\circ} \mathrm{F}\right)$ after desiccation to $<40 \%$ relative humidity $(\mathrm{RH})$ over saturated calcium chloride for $7 \mathrm{~d}$ at $4{ }^{\circ} \mathrm{C}\left(39^{\circ} \mathrm{F}\right)$ (Zambino et al., 1997). Spores were revived by submerging the envelopes in $40^{\circ} \mathrm{C}\left(104^{\circ} \mathrm{F}\right)$ water for $5 \mathrm{~min}$, then removing and rehydrating the spores for $4 \mathrm{~h}$ at $100 \% \mathrm{RH}$ and $4{ }^{\circ} \mathrm{C}$. Rehydrated spores were dispersed in $0.25 \%$ T ween 20 , pelleted by centrifugation, resuspended at a concentration of 0.1 $\mathrm{g}$ desiccated spores per $400 \mathrm{~mL}$ (13.5 fl oz) $0.07 \%$ water agar, and the suspension lightly misted onto the underside of leaves using a perfume atomizer attached to an air supply. After inoculation, plants and cuttings were incubated $24 \mathrm{~h}$ at $100 \% \mathrm{RH}$ and $20^{\circ} \mathrm{C}(68$ ${ }^{\circ} \mathrm{F}$ ), then placed in a greenhouse in full sun (plantsand cuttings), or in incubators and growth chambers with $12 \mathrm{~h}$ day/ night photoperiods at $25 / 25^{\circ} \mathrm{C}$ ( $77^{\circ} \mathrm{F}$ ) (cuttings only), or $20 / 15^{\circ} \mathrm{C}$ (68/59 ${ }^{\circ} \mathrm{F}$ ) (plants and cuttings). Cuttings were kept before and after inoculation in 5-cm (2-inch) diameter pots of fresh vermiculite within transparent plastic containers. During infection, containers were covered with tight-fitting plastic lids; after infection, a single covering of lab tissue provided air circulation and moderate humidity. Plants were misted and kept in plastic bags during infection.

M ost inoculations used Wisconsin isolate WI 4.1B from eastern white pine (PinusstrobusL.). H owever, one set of mature cuttings incubated at $20 / 15^{\circ} \mathrm{C}$ wasused to test the effect of WPBR strains from white pine species from across $\mathrm{N}$ orth America on black and red currant immunity to infection. Strains, listed by host of origin, were as follows: P. strobus(M E 1.1A, M E2.9B, MN1.1C, MN4.1A， MN6.1C, MN7.1C, MN9.1C, N H 1.1B, NY4.1A, VT 1.4A, WI 1.1C, WI4.1B); $P$. monticola D ougl. (Champion $M$ ine OR2.1A， OR2.3B); P. albicaulis
Engelm. (ID 1.5A); P. flexilis James (SD 1.1B，WY3.1B，WY5.1A); P. lambertiana D ougl. (CA2.1B, H appy Camp CA1.1C) and P. strobiformis Engelm. (N M 1.1B). The first two letters of each strain identification number indicates state of origin.

\section{Results and disc ussion}

I noculation of young but fully expanded leaves on intact plants or as single-leaf stem cuttings successfully identified immunity conferred by the $\mathrm{Cr}$ resistancegenein $\mathrm{R}$. nigrum. Abundant infections [ 13 to $29 / \mathrm{cm}^{2}$ (84 to 187/ inch ${ }^{2}$ )] developed within $9 \mathrm{~d}$ after inoculation on fresh and mature cuttings and the topmost leaves of rust-susceptible plants. I nfectionswere not as dense or uniform on lower and more mature leaves of intact plants, and infections were predominantly along veins in older leaves of cultivars Ben Lomond and Ben Alder. In contrast to susceptible cultivars, all tests of immune black currant cultivars Consort, C rusader, and Titania showed no signs of infection within $28 \mathrm{~d}$ of inoculation. Leaf scorching was noted on someplantsand cuttingskept in greenhouseconditions, suggesting the need for plants to be artificially shaded to prevent excessive leaf temperatures.

Results from red currant inoculations demonstrated the need for routine reassessment of resistance during development, propagation, and maintenance of resistant cultivars. Both of the sources presumed to represent the red currant cultivar Viking became infected, which suggests that an error in propagation or labeling may have been made at some time in the over 60 years since the immunity of this cultivar was first documented. The ' $\mathrm{Vi}$ king' used in this test could not be differentiated from susceptible red currant cultivar Red L ake in any set of inoculations on the basis of onset of urediniospore production, density of infections, and onset of teliospore production at $20 / 15^{\circ} \mathrm{C}$. Both cultivars also had similar onset of leaf necrosisin rust pustules on whole plants kept under greenhouse conditions after inoculation.

O ur results starkly contrast with previousreportsthat indicatethecomplete lack of successful infection and urediniospore production in 'Viking' in plants artificially inoculated with either aeciospores and urediniospores and grown under greenhouse or field conditions and in plants exposed to natural inoculum in the field (Anderson, 1939; H ahn, 1935, 1943). The most advanced signs of infection previously reported have been necrotic flecks that developed on very young leaves, approximately $2 \mathrm{~d}$ after artificial inoculation (Anderson, 1939). Ability to infect the presumed 'Viking' in the current studies under all conditions tested and with 21 different strains eliminates differences in environment and rust strain as causes for the unexpected results. Additional sources of 'Viking' are being sought. The rapid methods of assessing resistance described in this paper may then be used to identify a valid source of the ' $\mathrm{Vi}$ king' gene for immunity.

\section{Literature cited}

Anderson, O.C. 1939. A cytological study of resistance of Viking currant to infection by Cronartium ribicola. Phytopathology 29:26-40.

Brennan, R.M . 1996. Currantsand Gooseberries, III, p. 191-295. In: J. J anick and J.N . M oore (eds.). Fruit breeding. vol. 2. Small fruits and vine crops. Wiley, N ew York.

H ahn, G.G. 1935. Immunity of Viking, a N orwegian red currant, to Cronartium ribicola and $\mathrm{C}$ ronartium occidentaleunder greenhouse conditions. U SD A Circ. 330.

H ahn, G.G. 1943. Blister rust relations of cultivated species of red currants. Phytopathology 33:341-353.

Zambino, P., C. Echt, P. Pijut, and C. M ichler. 1997. Desiccation, storage temperature, and heat shock affect germination of $C$ ronartium ribicola urediniospores, aeciospores, and teliospores. I noculum 48:42 (abstr.). 